Volume 9 Issue 2 February 2021

\title{
LAW ENFORCEMENT SYSTEM OF TAXATION IN INDONESIA
}

\author{
Author: Zainal Muttaqin ${ }^{1}$, Dewi Kania Sugiharti ${ }^{2}$, Widati Wulandari ${ }^{3}$, \\ Muhamad Irfan Fadilla ${ }^{4}$, Amelia Cahyadini ${ }^{5}$
}

\author{
Affiliation: Faculty of Law University of Padjadjaran; Faculty of Law University of \\ Padjadjaran; Faculty of Law University of Padjadjaran; Faculty of Law University of \\ Padjadjaran; Faculty of Law University of Padjadjaran
}

Email: zm_fh76@yahoo.com; dewi@unpad.ac.id; widati.wulandari@unpad.ac.id;

m.irfanfadilla@gmail.com; amelia.cahyadini@unpad.ac.id

DOI: 10.26821/IJSRC.9.2.2021.9207

\begin{abstract}
Tax Law Enforcement has administrative sanctions and criminal sanctions as elements of law enforcement given by the two different agencies, namely tax officials and court judges, then the two types of sanctions can be imposed together or cumulatively. He emphasized that the administrative sanctions imposed do not necessarily eliminate criminal sanctions, and vice versa. If the coercive effort as regulated in the enforced warrant law is carried out by the DGT or uses Article 13A and Article 44B of Law Number 6 of 2009 concerning general provisions and procedures for taxation, then state losses as an element of a criminal act will not be fulfilled. To obtain data or information in writing this study, the author refers to a qualitative research approach, which refers to the norms and legal norms that live and develop in society. There is a symptom that the development of law enforcement in the context of tax revenue always uses criminal sanctions instruments without paying attention to the principle of cost-benefit principles and the capacity and capacity of the workforce of law enforcement officials.
\end{abstract}

Keywords: Tax Administration Sanctions; Tax Criminal Sanctions; Enforcement of Taxation Law.

\section{INTRODUCTION}

Tax is the most popular source of acceptance of the country in Indonesia than any other source of acceptance. This can be demonstrated by the percentage of tax revenues of approximately $78 \%$ of all receipts from government budgets and state expenditures. Therefore, the Government gave special attention to the taxation system in an effort to increase the acceptance of the tax sector. It is not excessive to say that a country's forward pullback will depend on its tax system.

Although tax revenues reach $78 \%$ of all revenues, however, when looking at the low tax ratio and tax coverage ratios, it means that there are still many potential taxpayers not paying or paying lower than they should. From the legal aspect, this indicates that there are still many taxpayers who commit violations of tax laws.

In order to support the success of tax revenues, Act No. 6 of 1983 as amended by Law No. 6 of 2009 on general provisions and procedures for Taxation (hereinafter abbreviated as Law on General Provisions and Procedures for Taxation) has been Provide a variety of sanctions that will be used as a law enforcement instrument in the field of taxation, which is intended to apply to all types of taxes. Even law No. 12 of 1985, as amended by Law No. 12 of 1994 on Earth and building tax and Law No. 13 of 1985 concerning Customs stamp, has also set up various sanctions to be imposed 
Volume 9 Issue 2 February 2021

either of taxpayers, third parties, or fiscus or tax officials.

Based on the three laws mentioned above, there are various sanctions, namely (1) Administrative sanctions, which consist of fines, interest and Ascension and (2) criminal sanctions, which can be either imprisonment or confinement and fines. Given the authority to impose both sanctions on the two different institutions, namely for the administrative sanction of their authority to be on tax officials and criminal sanctions are at court judges, then both types of sanctions may be dropped jointly or cumulatively. ${ }^{[1]}$ It is emphasized that the administration sanction that has been imposed does not necessarily eliminate criminal sanctions, nor vice versa.

In addition to the administrative sanctions and criminal sanctions, the legal system in taxation also recognizes other sanctions as a law enforcement instrument that is in the form of confiscation of taxpayer assets, auctions, and hostages (gijzeling) set in the Law number 19 of 2000 on tax billing with forced mail. A subpoena is the authority of the tax officer to be imposed if the taxpayer even if it is written in writing still does not pay off the taxes owed.

The issue arises when the above sanctions are associated with tax crimes. In either the Law on General Provisions and Procedures for Taxation, the UN law, as well as the stamp duty law, the tax crimes formula is always associated with the existence of the state loss element as a result of a taxpayer and a third party and fissure. If from the confiscated and the property auction shall be paid to settle the tax debt, but according to the criminal law system the settlement does not cause loss or deletion of the nature of deed against the law of the perpetrator. Similarly, the rationing of criminal sanctions does not cause the deletion of taxpayer debt.

In an effort to rule the law in taxation as an effort to increase state acceptance of the tax sector. There has been a lot of seized and auctions and reforming to taxpayers. Enforcement of taxation sanctions as a law enforcement instrument in the tax field is as if not to solve the legal problem completely, because the taxpayer's imprisonment does not waive the taxpayer's obligation to pay off

${ }^{[1]}$ Eddy O.S. Hiariej, "Perkembangan Hukum PidanaPajak, dalam Hukum Pidana Indonesia, 70 Tahun Prof. Komariah”, 2009, p. 204, unpublished. the tax debt. The tax enforcement system seems to emphasize more on the importance of State acceptance.

Based on the explanation above, this article intends to find the concept of the law enforcement system in the taxation area that provides legal certainty for the fiscus and other law enforcement and taxpayers. The problems that will be discussed is how the enforcement of administrative and criminal law in the field of taxation in the context of State acceptance? And how the concept of law enforcement in the field of taxation can provide legal certainty for taxpayers and law enforcement?

\section{RESEARCH METHODS}

To obtain data or information in the writing of this study, the authors refers to qualitative research approach, which is refers to the legal norms and norms that live and develop in society. The purpose of this qualitative research is to gain understanding, develop theories, and describe complexly. ${ }^{[2]}$ The analysis is presented in the form of descriptions, whereas if data is found and presented in the form of numbers, it is not intended to be tested statistically, but only to strengthen or sharpen the analysis.

Legal research generally has normative juridical and empirical juridical types. ${ }^{[3]}$ Considering that the law enforcement instruments in the field of taxation have been regulated in statutory regulations, this research was conducted using a normative juridical approach, in which the object of study was the legal norms that were formulated in the law by not ignoring the empirical facts contained in the field. ${ }^{[4]}$

We chose this method because research on the law enforcement system in the field of taxation is a descriptive study, a study that relating to legal theories that are the object of research and also law in its implementation in society. ${ }^{[5]}$ So the purpose of this study is to describe or carry out the implementation of law enforcement based on positive applicable law. State the objectives of your

${ }^{[2]}$ Zainuddin Ali, MetodePenelitian Hukum, Jakarta: SinarGrafika, 2009,p. 105.

${ }^{[3]}$ SoerjonoSoekanto, PengantarPenelitian Hukum, Jakarta: UI Press, 1986, p. 22.

${ }^{[4]}$ William H. Putman, Legal Research, Analysis and Writing, Australia: Thomson Delmar Learning, 2004, p. 76.

${ }^{[5]}$ Zainuddin Ali, MetodePenelitian Hukum, Jakarta: SinarGrafika, 2009, p. 106. 
Volume 9 Issue 2 February 2021

research and explain how to get the result. Explore your approach, specification dan analysis method in the perspective of law science.

\section{DISCUSSION}

\subsection{Tax Justice Theory}

Justice is an essential thing in human life, justice must be realized in every human relationship in order to be able to interpret the rule of law, eliminate legal impartiality, and remain in the essence of justice. ${ }^{[6]}$ Justice is basically a relative concept, everyone is unequal, fair according to one is not necessarily fair to another, when someone asserts that he is doing justice, it must be relevant to public order in which a scale of justice is recognized. ${ }^{[7]}$ The scale of justice varies greatly from one place to another, each scale is defined and fully determined by the community in accordance with the public order of that society. ${ }^{[8]}$

Justice must also be found in taxation, according to Adolf Wegner, fair tax collection is tax collection that is generally applied to all taxpayers and is imposed on every taxpayer who has the ability to pay evenly, that one tax rate structure applies to each taxpayer. who has the ability to pay (his journal). The greater the ability of a taxpayer to pay taxes, the greater the percentage of taxes that must be paid. There are two kinds of principles of justice in taxation:

a. Horizontal Equity, the administration of taxes must be general and equitable, which means that everyone who has the economic ability or who gets the same additional economic capacity must be subject to the same tax.

b. Vertical Equity, which relates to the obligation to pay taxes whose ability to pay is not the same, namely the greater the ability to pay taxes the greater the tax rate imposed.

${ }^{[6]}$ Sukarno Aburaera, Muhadar, and Maskun, Filsafat Hukum: Teori dan Praktik, Jakarta: KencanaPrenadamediaGrup, 2014, p. 15.

${ }^{[7]}$ ItsarNuryantoSambia, ImplementasiPrinsipKeadilanPemungutanPajakTer hadapPelaku E-Commerce, Makassar: Fakultas Hukum Unhas, 2018, p. 13.

${ }^{[8]}$ AgusSantoso, Law, Moral and Justice, 2nd Printing, Jakarta: Prenada Media, 2014, p. 56.

${ }^{[9]}$ Chairil Anwar Pohan, Comprehensive Discussion of Introduction to Taxation Theory and Concepts of Tax Law, 2nd Edition, Jakarta: Mitra Wacana Media, 2017, p. 43.
Horizontal justice achieved through the imposition of the same tax on all additional equal economic capacities regardless of sources of income and without distinguishing types of income. Taxpayers who get the same income with the same number of dependents regardless of the type of income or source of income will be subject to the same tax, only one kind of tax structure is applied, or what is commonly called equal treatment for the equals. ${ }^{[10]}$ Whereas in vertical equity the justice achieved through the imposition of different taxes if the amount of income of a taxpayer is different. The greater the amount of income of a taxpayer, the greater the tax rate that must be imposed on the taxpayer. ${ }^{[1]}$ In vertical equity, a progressive rate structure is required, namely the greater the net income of a taxpayer, the greater the tax rate and the difference in rates, namely the total amount of income or the total additional economic capacity, not because of differences in income sources or differences in income types, or usual called unequal treatment for the unequal. The principle of Vertical Equity is closely related to determining the amount of tax payable that must be paid by taxpayers.

Adam Smith in his book also provides a principle of fairness in tax collection which is known as the teaching of "The Four Maxims" which in one of the conditions is the principle of equity. This principle emphasizes the importance of balance based on the ability of each tax subject. This principle is expected to achieve justice (equity) among taxpayers, because they will be taxed based on their ability to pay taxes which are different between a taxpayer and other taxpayers. ${ }^{[12]}$ This principle is meant that the taxpayers or individuals or legal entities pay taxes equally and have the ability or ability to bear taxes so that they are perceived as fair together. Taxpayers together with other taxpayers pay taxes depending on the size of their ability, where

${ }^{[10]}$ ItsarNuryantoSambia,

ImplementasiPrinsipKeadilanPemungutanPajakTer hadapPelaku E-Commerce, Makassar: Fakultas Hukum Unhas, 2018, p. 17.

${ }^{[11]}$ Chairil Anwar Pohan, "Reviewing the Taxation Base of National Shipping Companies based on "Deemed Profit" on Income from Sea Transportation Business", Administrative Scientific Journal, 2016, p. 167.

${ }^{[12]}$ MarihotPahalaSiahaan, Elementary Tax Law, Yogyakarta: GrahaIlmu, 2010, p. 74. 
Volume 9 Issue 2 February 2021

taxpayers whose income is large and rich pay high taxes, while those with small or low and middle income pay enough tax.

John Rawls put forward two principles of justice, first, if everyone has the same right to the broadest basic freedom, as wide as the same freedom for all people. Then, the second is how to regulate social and economic inequality so that it can be expected to benefit everyone and all positions and positions are open to all people. ${ }^{[13]}$ So it can be concluded that justice in tax law is "equal treatment" to taxpayers, who do not differentiate between nationalities, both native and foreign, and do not differentiate between religions, political streams, and so on. Justice is also related to a legal process against parties who commit fraud against taxes which are the right of the state. Taxes are a source of state income that will be used to finance all general expenses, which means that they are used for the welfare of the people. Therefore, the state has a mechanism for sanctions against taxpayers who do not carry out their obligations as a form of achieving tax justice.

The state acts decisively basically starting from the existence of injustice. In the matter of taxation, for example, Plato said, "when there is income tax, just people will pay more than unfair people, even though they both get the same income". ${ }^{[14]}$ The issue of justice extends from the personal dimension to the social dimension, where tax avoidance is primarily a moral issue and has serious implications for the availability of sources of public spending financing. This means that when the state does not impose its will (enforces the law), a very large injustice will occur.

The manifestation in terms of upholding tax justice is set forth in the form of sanctions. In tax law enforcement in Indonesia, there are two types of sanctions, namely administrative sanctions and criminal sanctions. Tax administration law adheres to the principle of accident which results in taxpayers not paying tax debts according to the

${ }^{[13]}$ John Rawls, TeoriKeadilan: Dasar-Dasar FilsafatPolitikuntukMewujudkanKesejahteraanSosi aldalam Negara, Yogyakarta: Pustaka Pelajar, 2006, p. 57.

${ }^{[14]}$ YustinusPrastowo, Pajak dan Demokrasi: MenyoalKetimpangan, MendambaKesejahteraan, Dalam A. Prasetyantoko, SetyoBudantoro dan SugengBahagijo. Pembangunan Inklusif; Prospek dan Tantangan Indonesia, Jakarta: LP3ES dan Prakarsa, 2013, p.86. determined tax rates. Furthermore, in the tax administration process puts forward a persuasive approach, where as long as the taxpayer can pay off the tax debt, the taxpayer is not subject to tax sanctions. On the other hand, tax punishment is a form of crime, in which there is already deliberate behavior of the taxpayer to carry out a series of activities (usually leading to engineering) in order to avoid tax obligations as determined by law. The nature of the tax penal code is harsher with a number of criminal sanctions in the form of sorrow, both in the form of corporate punishment and fines, which are up to four times the tax payable.

Law enforcement is an effort to bring legal ideas and concepts that are expected by the people to come true. Law enforcement is a process that involves many things to bring the ideas of justice, legal certainty and social benefits into reality. ${ }^{[15]}$ The process of embodying these ideas is the essence of law enforcement. ${ }^{[16]}$ So it can be said that in tax law enforcement it is necessary to also pay attention to justice in society, legal certainty and also social benefits.

\subsection{Tax Sanctions in Indonesia: Administrative Law Perspective}

3.2.1. Understanding and Purpose of Law Enforcement

In the Literator, there are various opinions given by experts on the definition of law enforcement, such as SoerjonoSoekanto, JimlyAsshiddiqi, C.S.T. Kansil, SatjiptoRahardjo and so on. According to SatjiptoRahardjo, law enforcement is a process of realizing the law's desire to be the reality of the lawmaker's thoughts formulated in the rule of law. ${ }^{[17]}$

Meanwhile, according to SoerjonoSoekanto, law enforcement is the activity of the relationship of values that are described in the rules and attitudes of acts as a series of the description of the final stage value. ${ }^{[18]}$ This process or activity arises

${ }^{[15]}$ DellyanaShant, KonsepPenegakan Hukum, Yogyakarta: Liberty, 2000, p. 26.

${ }^{[16]}$ SatjiptoRahardjo, MasalahPenegakan Hukum: SuatuTinjauanSosialisasi, Bandung: SinarBaru, 1984, p. 24.

${ }^{[17]}$ SatjiptoRahardjo, MasalahPenegakan Hukum: SuatuTinjauanSosialisasi, Bandung: SinarBaru, 1984, p. 32.

${ }^{[18]}$ SoerjonoSoekanto, Faktor-faktor Yang MempengaruhiPenegakan Hukum, Jakarta: UI Press, 1983, p. 35. 
Volume 9 Issue 2 February 2021

as a result of unbalanced or inappropriate values that should be implemented with the fact that occurred. This means that the values or norms are not realized due to resistance from the party that should be subject to the stipulated value or norms, i.e. a breach of the norm, in other words, the occurrence of disobedient or not well-obedient to Legal obligations or prohibitions set by law.

In law enforcement, it contains two aspects, namely (1) The aspect of the procedure, that is, about how the law enforcement is conducted or by means of how law enforcement is implemented, and (2) who is authorized to conduct law enforcement. In the state system of the law, both aspects must be clearly regulated in the legislation, then law enforcement is not conducted through procedures or mechanisms that have been regulated or law enforcement carried out by agencies/agencies or officials is not authorized, it will cause violations of its own norm as an arbitrary act of law enforcement.

In the context of law enforcement Administration, norms or conventions enforced are the legal norms of state administration, in other words, the substance of the norm being violated is the legal norm of administration. Based on the explanation above, the purpose of law enforcement is to improve the norms or rules that are violated to "Steady" back as expected as intended or aspire by the legal establishment. Given the purpose of law enforcement is to restore the rules of the law to apply, then linking to the legal norm becomes the target to be achieved by law enforcement,

Due to this, there is a correlation between law enforcement and the purpose of the law itself, namely justice, certainty, and benefits. In this connection, law enforcement is a process of activities that aims to create justice, certainty and certainly the benefits and from the unity of the rules of the enforced law.

\subsubsection{Sanctions as Law Enforcement Implementation}

According to P. Nicolai means of law enforcement, State administration includes supervision and sanctions. ${ }^{[19]}$ Supervision is a preventative step to enforce compliance while the application of sanctions is a repressive action to

${ }^{[19]}$ Ridwan H.R., Hukum Administrasi Negara, Jakarta: PT. Raja GrafindoPersada, 2006, p. 311. force people to comply with the rules of law. Sanctions as a means of packaging is a form of state power in charge of enforcing the legal norm that the implementation is implemented by the agency or officials authorized by the laws and regulations.

Sanctions will not be issued or dropped if the result is adhered to, in other words, sanctions will be applied in case of violation of the legal norm. Sanctions are therefore inseparable from the rule of law. Without sanctions, no legal guarantees can be implemented in accordance with the legal purposes. Although sanctions are not an element of the rule of law, it is absolutely necessary for this context, sanctions are the instruments of law enforcement ten Berge argues that sanctions are the essence of law enforcement (administrative). It is not excessive to say that sanctions are the last part or door of any legal rule.

Sanctions in the State administrative law are public legal power tools used by the Government in response to the non-compliance of obligations contained in the legal norm of the State administration. The government's authority to impose this administrative sanction arises due to the authority to establish the legal norm of State administration. This is where the differences in administrative law enforcement with criminal law enforcement where criminal sanctions can only be dropped by court judges. The next difference according to Philipus, the concept of legal sanction of the state is aimed at its actions while in criminal law addressed to the perpetrator and the nature of the law sanction of Reparatory State administration. Condemnation is the restoration in the original state while providing its penalties while criminal sanctions are more Condemnatory, given the differences in the legal norm of State administration with criminal law, it can be possible sanctions or a coagulation relationship i.e. the perpetrator is given a subsidiary sanction, i.e. administrative sanctions and criminal sanctions simultaneously, due to law enforcement authorities on different institutions or officials.

Given the broader areas of government affairs, it is governed by their own laws and regulations, each of which has different administrative sanctions. This results in various administrative sanctions such as revocation of permits, governmental compulsion, enforcement of forced money, fine administration, termination of office and so on. In the field of taxation known 
Volume 9 Issue 2 February 2021

administrative sanctions in the form of fines, an increase in interest rates stipulated in the Law on General Provisions and Procedures for Taxation. In addition to criminal sanctions, there is also another sanction in the form of seized, auction, and hostages which are governed by the law of the Tax Collection Act with the forced letter.

\subsubsection{Sanctions in Taxes}

Taxes are known in various countries, considering that taxes are considered as a source of state acceptance that is critical for government maintenance financing. In addition, the tax also has a variety of functions and usability in the realization of state ideals, which in the unitary State of the Republic of Indonesia lies in the Pancasila and the opening 1945 Constitution of The Republic of Indonesia. ${ }^{[20]}$ This is in line with the state theory propounded by Jacobson and Lipman regarding the purpose and function of the country, where it is said that a tax poll system is an essential function of the country, i.e. the function required for continuation or The survival of the state, of which this view refers to the most major tax function in taxation literature called Budgeter function, namely to raise money to fill the state treasury. ${ }^{[21]}$

RochmatSoemitro Further view that tax is a state soul, because without a state tax is not or difficult to live unless the country has a sufficient income from natural resources to fulfill the needs of the State in carrying out its governance, so both opinions show that tax is an important thing in the life of state. ${ }^{[22]}$ Thus, the importance of tax on state life, then the state determines the legality of the matter in the respective state constitution, is not an exception to the Indonesian state that listed it in Article 23 a 1945 Constitution of The Republic of Indonesia, which reads 'taxes and other levies Regulated by law.' With the provision, the State has the right to make and execute a forced levy against the citizens whose applicability and enforcement are in force anyway. This is because the organization that can implement the tax function states, so that the people who are part of the country are required to comply and comply Indonesia.

${ }^{[20]} 1945$ Constitution of The Republic of

${ }^{[21]}$ G.A. Jacobson and M.H. Lipman, Political Science, College Outline Series, New York: Bernes \& Noble Inc, 1960, p. 243.

${ }^{[22]}$ RochmatSoemitro, Asas dan Dasar Perpajakan 1, Bandung: PT. Eresco, 1986, p. 45. with all provisions, including the tax provisions of the country for welfare and The sustainability of the country, which is in the tax legal literature is referred to as the theory of absolute tax obligations, therefore all provisions regarding taxes are governed by law Mandatory enforcement, so it is necessary to enforce the law in implementing the validity of the tax. ${ }^{[23]}$

Law enforcement itself is an activation process that aims to make the norm or rule applied as desired by the legislator so that it becomes a reality in the life of society. Thus, the purpose of enforcement is essential to realize the purpose of the law itself is to create justice, order and the validity of the law. In the enforcement of the law, the element of compulsion becomes important as a guarantee so that people submit to or obey the norms/conventions that apply so that the implementation of power in realizing the legal objectives above. Therefore, in the law of known adagium law without power is merely wishful and power without the law is iniquity. ${ }^{[24]}$

In its development, the enforcement of the law is reflected in each law by using criminal sanctions instruments as a means of structuring norms/rules, so there is a sense of criminalization of any violation of the norm/ Applicable rules. According to Sudarto, criminalization of certain deeds should pay attention to the principles of cost Benefit principle and capacity and ability of the working power of law enforcement agencies, do not exceed the burden Duties of law enforcement, then based on that view, the imposition of criminal sanctions against the violation of taxation laws should pay attention to the principles expressed by Sudarto, which is actually included in the regime Administrative law. ${ }^{[25]}$

In connection with this, WirjonoProdjodikoro stated that violations of the rules of civil law are resolved by the rules of civil law, violations of the administrative norms of law are resolved by using

${ }^{[23]}$ SantosoBrotodihardjo, PengantarIlmu Hukum Pajak, Bandung: PT Eresco, 1982, p. 31.

${ }^{[24]}$ MochtarKusumaatmadja, PengantarIlmu Hukum SuatuPengenalanPertama Ruang LingkupBerlakunyaIlmu Hukum, Bandung: Alumni, 2000, p. 87.

${ }^{[25]}$ Sudarto, KapitaSelekta Hukum Pidana. Bandung: Alumni, 2006, p. 62. 
Volume 9 Issue 2 February 2021

the rules of Administrative law. ${ }^{[26]}$ If this opinion applied to tax violations, then the principle of ultimumremedium must be placed in the final process of enforcement, meaning that criminal sanctions for violations of tax law should be applied when Enforcement of administrative law cannot be applied to the principle of ultimumremedium without being adopted in article 44B Jo. Article 13a of Law on General Provisions and Procedures for Taxation as a form of law enforcement through proceedings outside the court (nonlitigation). ${ }^{[27]}$

\subsection{The Law Enforcement in Tax between Criminal Law Versus Administrative Law}

3.3.1. Criminal Sanctions Versus

\section{Administrative Sanctions}

It has been the tendency of almost all administrative laws in Indonesia using criminal sanctions as a means for the enforcement of norms or principles on the basis of the assumption that the administrative facilities are not effective enough to the country's administrative legal certainty. The granting of permits is stipulated by taxation. As a result, tax laws include criminal sanctions in addition to administrative sanctions and this causes there to be slices over administrative sanctions and criminal sanctions. Criminal sanctions are a consequence of any criminal cause or event committed by a person or legal entity specified in the law. In simple tax criminal act is a criminal offense conducted in the field of taxation. The question is if criminal law enforcement and State administrative law enforcement are conducted? In relation to this issue explanation of Article 38 of the Law on General Provisions and Procedures for Taxation confirms that "the breach of tax obligations carried out by the taxpayer, as long as the tax administration measures the taxation of administrative sanctions issued, while the Criminal offense is subject to criminal sanctions ". Acts and actions referred to in Article 38 of Law on General

${ }^{[26]}$ WirjonoProdjodikoro, Asas-Asas Hukum Pidana di Indonesia, Bandung: PT. RefikaAditama, 2003, p. 17.

${ }^{[27]}$ Zainal Muttaqin, Dewi KaniaSugiharti, and I. Tajudin, "Law Enforcement on Taxation ThroughtNon Litigation Mechanism (An Alternative)", Mimbar Hukum UGM, Vol. 27, Number 2, 2015, p. 26.
Provisions and Procedures for Taxation is not a violation of administration but is a criminal offense. ${ }^{[28]}$ The criminal sanction is expected to be a taxpayer awareness to comply with tax obligations. From the explanation of Article 38 of the Law on General Provisions and Procedures for Taxation, there are two important things to be studied, namely (1) administrative violations given administrative sanctions and criminal acts given by criminal sanctions and (2) the emergence of compulsory awareness to comply with tax obligations due to criminal sanctions. The Law on General Provisions and Procedures for Taxation determines some of the acts of administrative violations that are subject to administrative sanctions:

a. Do not deliver the Annual Notification Letter (SPT) until the deadline specified before published Underpaid Tax Assessment Letter (SKPKB) (fines) Article 7 paragraph (1) Jo. Paragraph (2a);

b. To correct the Annual Notification Letter (SPT), which resulted in tax payable more pay (interest) in Article 8 paragraph (2);

c. By his own will reveal not true his deeds before the investigation (fines);

d. The underpaid taxes are paid as a result. Disclosure is not correct Annual Notification Letter (SPT) (increment) Article 8 paragraph (5);

e. Payment or withholding tax made after the due date (penalty) Article 9 paragraph (2a);

f. Shortage of tax payments based on Underpaid Tax Assessment Letter (SKPKB) as a result of inspection or other information and the SPT is not delivered a specified period greetings (interest);

g. Taxpayer does not conduct the bookkeeping, does not show the bookkeeping to the tax inspectors, the taxpayer is given the Taxable employers (NPWP/PKP) in position, the taxpayer must compensate the difference in tax or should not be charged $0 \%$ rate (increase);

h. Taxpayer after a five-year period after tax payable, expired tax, published Underpaid Tax Assessment Letter for committing a criminal offence in the field of taxation or other criminal offence that could incur losses in the

${ }^{[28]}$ Law Number 6 Year 1983 as amended by Law Number 6 Year 2009 on General Provisions and Taxation Procedures. 
Volume 9 Issue 2 February 2021

state income based on A court ruling that has had a fixed legal force (interest);

i. Taxpayers for the first time due to their absence do not convey Annual Notification Letter or convey Annual Notification Letter but its contents are incorrect or incomplete or attach information that is not correct so that it can inflict losses on state revenues (Hike);

j. Income Tax (PPh) in the year is not or less paid, the shortage of tax payments as a result of miswritten or miscalculated (interest);

k. Entrepreneurs who have been confirmed as Taxable employers do not create tax invoices or create tax invoices but not timely, entrepreneurs who have been confirmed as Taxable employers do not fill in the full tax invoice, Taxable employers report tax invoices do not match the time Issuance of tax invoices (fines);

1. Shortage of tax payments in Underpaid Tax Assessment Letter (increment);

m. Taxpayers after a period of five years after the time of tax payable or the expiration of the tax mass issued by Additional Underpayment Tax Assessment Letter due to committing crimes in the field of taxation or other criminal acts that could incur losses in revenues State based on a court ruling that has a fixed legal force;

n. Appeal rejected or partially granted (penalty);

o. Termination of investigation (fines).

Administrative sanctions in tax law, other than in the Law on General Provisions and Procedures for Taxation, are also available in Law Number 12 Year 1985 on Earth and Building

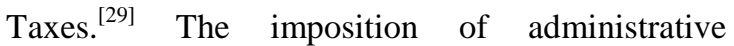
sanctions is imposed if:

a. Tax Object Notification Letter is not delivered within the specified time period (fines);

b. Taxpayers are subject to Tax Assessments (penalty);

c. The UN is paid after the payment due (penalty).

Meanwhile, in Law Number 13 Year 1985 concerning the Customs stamp of duty is also known administrative sanction imposed in the event that the document owed stamp duty is not or

${ }^{[29]}$ Law Number 12 Year 1985 as amended by Law Number 12 Year 1994 on Earth and Building Taxes. less paid. ${ }^{[30]}$ Furthermore, to distinguish the deeds imposed by the administration sanction and the deeds imposed by criminal sanctions, it is necessary to seek understanding and elements of the deed that can be categorized as a criminal offence in the field of taxation. RocmatSoemitro distinguishes between fiscal crimes and tax crimes, fiscal criminal acts have a broader understanding of tax crimes considering the fiscal sense itself wider than the tax Including everything that is related to state finances such as Non-tax revenue State Treasury, Excise, retribution, duties, and so on. ${ }^{[31]}$

Normatively there is no formulation or definition of criminal acts stipulated in legislation included in the Law on General Provisions and Procedures for Taxation which is the provisions of the law applicable to all types of taxes. The formula of criminal offence is determined in the explanation of Article 33 paragraph 3 of Law Number 25 Year 2007 on Investing which reads:'The tax criminal is incorrect information regarding the report related to the tax collection by conveying the notification letter but whose contents are incorrect or incomplete or attaching an incorrect information so that the country and any other crimes governed by the laws governing taxation., ${ }^{[32]}$

There are several articles governing acts or acts categorized as a criminal offence in the Law on General Provisions and Procedures for Taxation, namely:

a. Article 38 which reads:"Every person who is for his or her own will:

1) Not delivering the Annual Notification Letter;

2) Convey the Annual Notification Letter, but the contents are incorrect or incomplete or attach information that is not correct so it can inflict losses on the revenue of the country."

b. Article 39 which reads:"Everyone who intentionally:

1) Do not register for a Tax ID number or report the effort to be confirmed as a Taxable employers;

${ }^{[30]}$ Law Number 13 Year 1985 on Stamp Duty.

${ }^{[31]}$ RochmatSoemitro, Asas dan Dasar Perpajakan 1, Bandung: PT. Eresco, 1986, p. 52.

${ }^{[32]}$ Law Number 25 Year 2007 on Investing. 
Volume 9 Issue 2 February 2021

2) Misuse or use without the right of Tax ID number or confirmation of the Taxable employers;

3) Not delivering the Annual Notification Letter;

4) Convey the Annual Notification Letter and/or description whose contents are incorrect or incomplete;

5) Rejected the examination as referred to Article 29;

6) Show books, records, or other documents that are false or falsified as if they were true or do not depict their actual circumstances;

7) does not conduct bookkeeping or recording in Indonesia, does not show or do not lend books, records or other documents;

8) Do not store books or records or documents that are the basis of bookkeeping or recording and other documents including the results of data processing from a bookkeeping that is electronically managed or conducted on an Online application program in Indonesia as referred to in Article 28 paragraph (11);

9) Do not deposit any taxes that have been deducted or collected."

c. Article 39A reads:"Everyone who accidentally:

1) Issuing and/or using tax invoices, tax receipts, proof of withholding taxes and/or proof of tax deposit that is not based on actual transactions.

2) issued a fixed tax invoice has not been confirmed as a taxable employee.

Besides the deeds above that are governed in the Law on General Provisions and Procedures for Taxation there are also acts or criminal acts governed by the UN law and the stamp duty law. The criminal provisions in the tax laws specified in the UN law are contained in Article 24 i.e. because of its determination:

a. Does not return/deliver Tax Object Notification Letter;

b. Convey the Tax Object Notification Letter, but the contents are incorrect or incomplete and/or attach an incorrect information, thus causing losses to the state.

The criminal provisions are deliberately made:

a. Does not return/deliver Tax Object Notification Letter; b. Convey the Tax Object Notification Letter, but the contents are incorrect or incomplete and/or attach incorrect information;

c. Shows false or forged letters or other documents that are false or falsified as if they were true;

d. Does not show or do not lend letters or other documents;

e. Does not show any data or does not convey the necessary information to cause harm to the country.

Criminal sanctions against intentional deeds are heavier than criminal acts committed due to fornication. Meanwhile, the criminal provisions of the stamp duty law shall be imposed on the following actions:

a. Imitating or faking stamp and stamp paper or imitating and faking signatures that are necessary to misrepresent seals;

b. Deliberately save with the intent to be circulated or incorporated into the state of Indonesia false seal, which is forged or made against the rights;

c. Deliberately use, sell, offer, submit, provide for sale or put into the state of Indonesia the brand's seal, his mark, his or her valid sign of time is omitted as if the seal was Not yet used and or telling others to use it against the right;

d. Storing materials or tools he knew was used to do one of the evils to replicate and falsify the seal objects;

e. Use other means of repayment of stamp duty without permission of the Minister of Finance.

Given that authority that impose on criminal sanctions and administrative sanctions is different, whether it is not closed the taxpayer may be charged at once or simultaneously in the circumcision brackets, as well as the implementation of the authority is not mutually Remove each other. This means that the administrative sanctions imposed by the tax authorities do not eliminate the authority of court judges to impose criminal sanctions and vice versa. For example, if the taxpayer is inspected by the fiscus and it turns out that the Annual Notification Letter is incorrect or incomplete so it is known that there is a shortage of pay, then in this case the taxpayer may be subject to Underpaid Tax Assessment Letter as stipulated in article 13 paragraph (1) of the law General Provisions and Procedures for Taxation in which contains administrative sanctions. The taxpayer is obviously 
Volume 9 Issue 2 February 2021

detrimental to the income of the state threatened by criminal sanction by Article 38 of Law on General Provisions and Procedures for Taxation. If the taxpayer does not use the provisions of Article 44B of the Law on General Provisions and Procedures for Taxation then the taxpayer may be subject to criminal sanction in addition to the administrative sanctions as referred to Article 13 paragraph (1) of the Law on General Provisions and Procedures for Taxation (before the revision by Omnibus Law).

\subsubsection{Criminal Investigation}

\subsubsection{Authority of Investigation}

The investigation is one of the stages in the criminal law enforcement process set out in the Criminal Procedure Code, a series of investigators to seek and to gather evidence with evidence to make light about the crimes that took place and to find their suspects. According to Article 6 of the criminal CODE, investigators are police officers and civil servants officials who are given special authority by law. Unlike the police investigator's authority, police officers and civil servants authority is governed by the laws of their respective legal bases. Specialized in tax crimes, investigations are conducted only by police officers and civil servants in the Environment of the Directorate General of Taxation (Article 44 of the Law on General Provisions and Procedures for Taxation).

This means those police investigators are unable to conduct investigations into taxation, but the Investigator police officers and civil servants Directorate General of Taxation should notify the commencement of the investigation and convey the results of its investigation to the prosecution through Police investigators. This requirement remembers the position of police officers and civil servants under the coordination and supervision of police investigators. Although tax police officers and civil servants are given special authority in tax criminal investigation their authority as tax investigators is different from police investigator authority. There is a police investigator authority that is not owned by the tax investigator police officers and civil servants, such as conducting arrests and detention. Therefore, in case of consideration need to be committed to the taxpayer who commits a tax criminal offense, tax police officers and civil servants must ask for assistance to the police investigator so that the detention order is not carried out by tax police officers and civil servants but over the police investigator.

In practice arises whether tax police officers and civil servants can confiscation on goods or property of taxpayers that allegedly constitute a result of tax crimes, beyond foreclosure on bookkeeping, documents, recording as evidence as Referred to Article 44 paragraph (2) letter F of the Law on General Provisions and Procedures for Taxation. According to the results of interviews with tax police officers and civil servants, this issue is a barrier so far because it cannot be done given Article 44 paragraph (2) Letter F Law on General Provisions and Procedures for Taxation only gives limited authority. To make foreclosure on a taxpayer's alleged goods or possessions of a criminal offense should be linked to a corruption criminal offense or a money-laundering criminal. As a consequence, if the confiscated taxpayer treasures are due to the reason of corruption or corruption criminal offense or a money-laundering criminal, the auction proceeds are no longer an acceptance of the tax sector, but rather a state acceptance instead of tax (PNBP). To resolve this issue tax police officers and civil servants can use the legal basis of Article 44 paragraph 2 letter k of the Law on General Provisions and Procedures for Taxation which is the authority to perform other measures necessary for the smooth investigation of tax crimes so there is no need to wait for the investigation Corruption or corruption criminal offense or a money-laundering criminal.

Based on the authority above, who knows whether or not the criminal act in the taxation sector is only the Directorate General of Taxation as a result of preliminary proof examination which is the development of bookkeeping checks or held by the taxpayer. The examination which is the authority of the Directorate General of Taxation not only aims to test compliance with taxpayer tax obligations but also for other purposes in order to enforce the provisions of tax legislation. Thus, the authority of the Directorate General of Taxation in the case of inspection is very broad both concerning place, tax type, tax year, and so on. Preliminary proof examination is an examination made to obtain preliminary evidence about the alleged tax criminal, therefore the result of preliminary evidence examination is the basis for the investigation conducted by the tax police officers and civil servants is an indication that there is a criminal offense thus the preliminary evidence 
Volume 9 Issue 2 February 2021

test aims to obtain initial evidence of alleged taxation crimes based on the results of development and analysis of information, data, reports, or Complaints from third parties. If the result of the preliminary proof test is found the preliminary evidence of criminal activity will be followed by an investigation. Conversely, if there is no evidence of the beginning of a criminal offense, it will not continue at the next stage of the investigation, information, and reports or complaints are deemed not to exist.

It has become a common principle in criminal law that the investigation of criminal acts will not necessarily end with prosecution by the prosecutor or the examination process in court. This is stated in Article 109 clause (2) of the criminal CODE governing the reason can be a stop investigation, namely:

a. There is not enough evidence

b. Such events are not a criminal law act

c. For the sake of law, because:

1) The defendant died

2) Nebis in idem

3) The case has been in evidence

The same provisions are found also in Article 44A of Law on General Provisions and Procedures for Taxation as a legal basis for tax police officers and civil servants to cease the investigation of tax crimes. Although Article 44A of the Law on General Provisions and Procedures for Taxation does not refer to Nebis in idem as to the reason for termination of the investigation but considering the tax crime is essentially a general criminal act then, the principle nebis in idem referred to in Article 76 criminal CODE with itself applies to tax crimes. ${ }^{[33]}$

\subsubsection{Criminal Sanctions Exemption}

As previously mentioned, tax laws contain criminal legal aspects when the violated norms provide threats with criminal sanctions, even if tax laws are essential including administrative legal regime. In General Taxation Provisions Law there are several provisions that intersect between administrative sanctions with criminal sanctions involving investigation, namely:

First, Article 8 paragraph (3) of Law on General Provisions and Procedures for Taxation. Pursuant to this provision of the taxpayers who have been conducted the examination because of

${ }^{[33]}$ Criminal Code of Indonesia. alleged tax criminal acts as stipulated in Article 38 of the next section of the Law on General Provisions and Procedures for Taxation will not be investigated if the taxpayer Concerned with his own willingness to disclose the untruth of his actions, by settling the shortage of tax payments owed by plus the administrative sanction of fines of $150 \%$ of the amount of tax is less paid. By not doing the investigation, the prosecution and trial proceedings will not occur. The article can only be applied if the taxpayer has not been investigated. Therefore, if the taxpayer is or has been conducted an investigation, then Article 8 paragraph (3) shall not be applied.

The imposition of the administrative fine and the payment of tax payable in this article is more of a precautionary implementation of Article 38. If the taxpayer does not pay the investigation action by tax police officers and civil servants will continue. The current question is whether with the continuing investigation then the prosecution until the delegate to the court can be determined that the taxpayer will be sentenced to criminal as stipulated in Article 38 of the Law on General Provisions and Procedures for Taxation? Of course, this will depend on the proof of the trial because the authorities to impose criminal sanctions are court.

Second,Article 13A Law on General Provisions and Procedures for Taxation. This article governs the release of criminal sanctions against taxpayers due to its determination, i.e. (1) not entering the Annual Notification Letter; (2) Enter the Annual Notification Letter but the contents are not right or incomplete; (3) Attaching information that is not correct so that it can cause losses in the state revenue. The exemption from criminal sanctions is provided on the condition thatthe omission made by the taxpayer is the first act of action and the taxpayer pays off the tax payment along with the administrative sanctions of the increase of $200 \%$ from the amount of tax payment as stated in Underpaid Tax Assessment Letter.

Pay attention to the above conditions so if the taxpayer's action is done for the second time or onwards then the provisions of Article 13A will become void. This article is not clear whether enforced before or after the enforcement. In the Law on General Provisions and Procedures for Taxation, Underpaid Tax Assessment Letter is governed by Article 13 paragraph (1) which does not exist with a tax crime, and the issuance of 
Volume 9 Issue 2 February 2021

Underpaid Tax Assessment Letter is the result of inspection as a result of an administrative violation that does not necessarily indicate the existence of Criminal. By Omnibus Law, this article has been deleted.

Third,Article 44B of Law on General Provisions and Procedures for Taxation. This article governs the possibility of the establishment of a criminal investigation by the attorney general at the request of the Minister of Finance with consideration for the benefit of receipt of state money. Termination of inquiry can be made on condition (1) in the period of six months from the request of the Minister of Finance; (2) The taxpayer pays off the tax payable which is not or less paid as well as the penalty plus a fine of four times the amount of tax that is not or less paid; (3) Criminal matters have not been delegated to the court.

The issue arises as to whether this provision applies to a taxpayer who is the first to commit a criminal offense as stipulated in Article 13A Jo. Article 38 of the Law on General Provisions and Procedures for Taxation or also applies to taxpayers who have repeated criminal acts. The provisions of Article 44b shall not be recognized in the principle of termination of inquiry set forth in the Criminal Code as described previously so that in this case the principle of Lex specialist derogate Lex Generalist. By observing the formulation of Article 44B above the apparent taxation legislation is more emphasis on tax function as a source of state acceptance than using criminal sanctions this can be understood because the state's taxpayer punitive will not Guaranteed tax repayment. The application of criminal sanctions in the form of imprisonment or confinement does not result in paid tax debt, the tax payable remains attached to the taxpayer.

The question arises, whether by a stop the investigation of the nature of deeds against the law becomes lost? Theoretically, even if a criminal investigation is terminated or not followed by a taxpayer's reason to settle the payable taxes and penalties, however, the nature of the deed against the law that has been done by the taxpayer is not lost. The taxpayer's conduct is still against the law. However, by paying off the tax debt, the losses to the country's revenue as a criminal act are not fulfilled. Considering criminal sanctions do not waive tax debts, whether against taxpayers who have undergone criminal penalties can be punished again by reason of tax payable still attached to taxpayers? In this case, it will apply the principle of nebis in idem for the same taxation of criminal law. Therefore, the legal certainty for both taxpayers and investigators or law enforcement should have a clear arrangement in the Law on General Provisions and Procedures for Taxation on the application of the principle.

\subsubsection{Forced Efforts}

In the terminology of administrative law, forced efforts have a sense as one form of sanctions that the implementation is done by the administration of the State itself without the need of a court judgment. In tax law, this forced effort is governed by law No. 19 of 2000 regarding tax collection with forced mail. ${ }^{[34]}$ This forced letter can be defined as a warrant of paying the tax debt along with the billing charges with the threat of seized, auction, and hostages and has an executorial title and has a binding legal force such as a court ruling that has been Having a fixed legal force (in kracht van gewijsde). The Tax collection Act with a forced letter is an implementation of Article 20 paragraph 1 of the Law on General Provisions and Procedures for Taxation which reads: 'Above the amount of tax that is still payable based on tax bill, Underpaid Tax Assessment Letter, Additional Underpayment Tax Assessment Letter, correction decision letter, decision letter objection, appeal decision and re-review ruling which causes the tax amount to be paid That is not paid by the tax insurer as specified in Article 9 paragraph 3 or paragraph $3 \mathrm{~A}$ is carried out tax collection with a forced letter.'

Pursuant to the Article, the forced letter is part of the billing process so that it is a law enforcement instrument when the taxpayer does not pay off the tax debt at the specified time therefore in the structure of the Organization of Tax Directorate General Has its own standing, separate from the sexy opponents and investigations?

However, when paying attention to the content of the decision in the forced letter, it can also be said that the issuance of forced letters as well as sanctions beyond criminal sanctions because if the taxpayer does not pay off the tax debt as stated in the Tax collection letter, Additional Underpayment Tax Assessment Letter

${ }^{[34]}$ Law Number 19 Year 2000 on Tax Billing WithForced Mail. 
Volume 9 Issue 2 February 2021

and so on will have the consequences of the seizure of the taxpayer's possession both moving goods and the goods are not turbulent. The taxpayer's possession is the collateral for the repayment of the tax debt. If the taxpayer is not paying off the tax debt until the deadline specified then the confiscated property will be auctioned through the state auction office, and the taxpayer's property auction will be used to settle the tax debt. The next forced attempt is in the form of a hostage-taking, a temporary prohibition of taxpayer freedom by placing it in a particular place or in other words imprisoned, therefore the hostage in the framework of the forced attempt is similar to A different criminal sanction is the hostage-taking is reasonably based on the decision of tax administration officials, not through a court judge verdict. Given nature, then to do the hostage is required condition, namely (1) Taxpayer debt at least 100 million; (2) doubt the good faith; and (3) there must be written permission from the finance minister to the central tax and the governor for the local tax.

\section{CONCLUSION}

From the perspective of termination of the investigation, law enforcement is more emphasis on administrative sanctions in consideration of the acceptance of countries sourced from tax payable and administrative sanctions. Therefore, criminal sanction more than the new ultimumremedium will be applied if the taxpayer does not meet the administrative sanctions. By allowing the application of administrative sanctions and criminal sanctions simultaneously (cumulation), it raises the position uncertainty about criminal sanctions as ultimumremedium. Criminal sanctions who dropped to taxpayers do not cause the deletion of tax debt and also does not eliminate the nature of the action against the deed, therefore it is unfair if the taxpayer who has undergone criminal penalties still have the potential applied the second time criminal sanctions.

\section{SUGGESTION}

In the investigation process related to tax crimes, there are interesting things related to Article 44B of Law on General Provisions and Procedures for Taxation which states, for the benefit of state revenue, the Attorney General at the request of the Minister of Finance can stop the investigation if the taxpayer has paid off the unpaid or underpaid tax debt with added sanctions. administration in the form of a fine of four times the amount of unpaid or underpaid tax

Termination of investigation at the request of the minister of finance to the attorney general is carried out with the intention not only to impose criminal sanctions as is generally given to perpetrators of criminal acts, but how to make the public understand the provisions of the tax law in order to optimize state revenue. In principle, the purpose of tax law is not to criminalize taxpayers but how to realize tax money as a source of state revenue. In this case, tax law is more oriented towards the benefit principle for the benefit of state revenue, not for criminalizing. Therefore it is necessary to conduct further research on the effectiveness of the provisions referred to. Termination of investigations based on the provisions of Article 44B of Law on General Provisions and Procedures for Taxation can be considered positive when viewed from the point of view of state revenue, based on the philosophy of tax law. However, the termination can also be deemed ineffective in terms of legal certainty, which should be continued at the prosecution and trial level. The next question that arises is where is the legal certainty if all tax crimes can be replaced with an amount of money without the completion of the criminal process?

\section{REFERENCE}

[1]. Eddy O.S. Hiariej, "Perkembangan Hukum PidanaPajak, dalam Hukum Pidana Indonesia, 70 Tahun Prof. Komariah”, 2009, p. 204, unpublished.

[2]. Zainuddin Ali, MetodePenelitian Hukum, Jakarta: SinarGrafika, 2009, p. 105.

[3]. SoerjonoSoekanto, PengantarPenelitian Hukum, Jakarta: UI Press, 1986, p. 22.

[4]. William H. Putman, Legal Research, Analysis and Writing, Australia: Thomson Delmar Learning, 2004, p. 76.

[5]. Zainuddin Ali, MetodePenelitian Hukum, Jakarta: SinarGrafika, 2009, p. 106.

[6]. Sukarno Aburaera, Muhadar, and Maskun, Filsafat Hukum: Teori dan Praktik, Jakarta: KencanaPrenadamediaGrup, 2014, p. 15.

[7]. ItsarNuryantoSambia, ImplementasiPrinsipKeadilanPemungutanPa 
Volume 9 Issue 2 February 2021

jakTerhadapPelaku E-Commerce, Makassar:

Fakultas Hukum Unhas, 2018, p. 13.

[8]. AgusSantoso, Law, Moral and Justice, 2nd Printing, Jakarta: Prenada Media, 2014, p. 56.

[9]. Chairil Anwar Pohan, Comprehensive Discussion of Introduction to Taxation Theory and Concepts of Tax Law, 2nd Edition, Jakarta: Mitra Wacana Media, 2017, p. 43.

[10]. ItsarNuryantoSambia, ImplementasiPrinsipKeadilanPemungutan $\mathrm{Pa}$ jakTerhadapPelaku E-Commerce, Makassar: Fakultas Hukum Unhas, 2018, p. 17.

[11]. Chairil Anwar Pohan, "Reviewing the Taxation Base of National Shipping Companies based on "Deemed Profit" on Income from Sea Transportation Business", Administrative Scientific Journal, 2016, p. 167.

[12]. MarihotPahalaSiahaan, Elementary Tax Law, Yogyakarta: GrahaIlmu, 2010, p. 74.

[13]. John Rawls, TeoriKeadilan: Dasar-Dasar FilsafatPolitikuntukMewujudkanKesejahtera anSosialdalam Negara, Yogyakarta: Pustaka Pelajar, 2006, p. 57.

[14]. YustinusPrastowo, Pajak dan Demokrasi: MenyoalKetimpangan,

MendambaKesejahteraan, Dałam A. Prasetyantoko, SetyoBudantoro dan SugengBahagijo. Pembangunan Inkhusif; Prospek dan Tantangan Indonesia, Jakarta: LP3ES dan Prakarsa, 2013, p.86.

[15]. DellyanaShant, KonsepPenegakan Hukum, Yogyakarta: Liberty, 2000, p. 26.

[16]. SatjiptoRahardjo, MasalahPenegakan Hukum: SuatuTinjauanSosialisasi, Bandung: SinarBaru, 1984, p. 24.

[17]. SatjiptoRahardjo, MasalahPenegakan Hukum: SuatuTinjauanSosialisasi, Bandung: SinarBaru, 1984, p. 32.

[18]. SoerjonoSoekanto, Faktor-faktor Yang MempengaruhiPenegakan Hukum, Jakarta: UI Press, 1983, p. 35.
[19]. Ridwan H.R., Hukum Administrasi Negara, Jakarta: PT. Raja GrafindoPersada, 2006, p. 311.

[20]. 1945 Constitution of The Republic of Indonesia.

[21]. G.A. Jacobson and M.H. Lipman, Political Science, College Outline Series, New York: Bernes \& Noble Inc, 1960, p. 243.

[22]. RochmatSoemitro, Asas dan Dasar Perpajakan 1, Bandung: PT. Eresco, 1986, p. 45.

[23]. SantosoBrotodihardjo, PengantarIlmu Hukum Pajak, Bandung: PT Eresco, 1982, p. 31.

[24]. MochtarKusumaatmadja, PengantarIlmu Hukum SuatuPengenalanPertama Ruang LingkupBerlakunyallmu Hukum, Bandung: Alumni, 2000, p. 87.

[25]. Sudarto, KapitaSelekta Hukum Pidana. Bandung: Alumni, 2006, p. 62.

[26]. WirjonoProdjodikoro, Asas-Asas Hukum Pidana di Indonesia, Bandung: PT. RefikaAditama, 2003, p. 17.

[27]. Zainal Muttaqin, Dewi Kania Sugiharti, and I. Tajudin, "Law Enforcement on Taxation ThroughtNon Litigation Mechanism (An Alternative)", Mimbar Hukum UGM, Vol. 27, Number 2, 2015, p. 26.

[28]. Law Number 6 Year 1983 as amended by Law Number 6 Year 2009 on General Provisions and Taxation Procedures.

[29]. Law Number 12 Year 1985 as amended by Law Number 12 Year 1994 on Earth and Building Taxes.

[30]. Law Number 13 Year 1985 on Stamp Duty.

[31]. RochmatSoemitro, Asas dan Dasar Perpajakan 1, Bandung: PT. Eresco, 1986, p. 52.

[32]. Law Number 25 Year 2007 on Investing.

[33]. Criminal Code of Indonesia.

[34]. Law Number 19 Year 2000 on Tax Billing With Forced Mail. 